\title{
Coupling a land-surface model with a crop growth model to improve ET flux estimations in the Upper Ganges basin, India
}

\author{
G. M. Tsarouchi ${ }^{1,2}$, W. Buytaert ${ }^{1,2}$, and A. Mijic ${ }^{1}$ \\ ${ }^{1}$ Department of Civil and Environmental Engineering, Imperial College London, London, UK \\ ${ }^{2}$ Grantham Institute for Climate Change, Imperial College London, London, UK \\ Correspondence to: G. M. Tsarouchi (g.tsarouchi11@imperial.ac.uk)
}

Received: 3 June 2014 - Published in Hydrol. Earth Syst. Sci. Discuss.: 26 June 2014

Revised: 19 September 2014 - Accepted: 22 September 2014 - Published: 28 October 2014

\begin{abstract}
Land-Surface Models (LSMs) are tools that represent energy and water flux exchanges between land and the atmosphere. Although much progress has been made in adding detailed physical processes into these models, there is much room left for improved estimates of evapotranspiration fluxes, by including a more reasonable and accurate representation of crop dynamics. Recent studies suggest a strong land-surface-atmosphere coupling over India and since this is one of the most intensively cultivated areas in the world, the strong impact of crops on the evaporative flux cannot be neglected. In this study we dynamically couple the LSM JULES with the crop growth model InfoCrop. JULES in its current version (v3.4) does not simulate crop growth. Instead, it treats crops as natural grass, while using prescribed vegetation parameters. Such simplification might lead to modelling errors. Therefore we developed a coupled modelling scheme that simulates dynamically crop development and parametrized it for the two main crops of the study area, wheat and rice. This setup is used to examine the impact of inter-seasonal land cover changes in evapotranspiration fluxes of the Upper Ganges River basin (India). The sensitivity of JULES with regard to the dynamics of the vegetation cover is evaluated. Our results show that the model is sensitive to the changes introduced after coupling it with the crop model. Evapotranspiration fluxes, which are significantly different between the original and the coupled model, are giving an approximation of the magnitude of error to be expected in LSMs that do not include dynamic crop growth. For the wet season, in the original model, the monthly Mean Error ranges from 7.5 to $24.4 \mathrm{~mm} \mathrm{month}^{-1}$, depending on different precipitation forcing. For the same season, in the coupled model, the monthly Mean Error's range is reduced to 5.4-
\end{abstract}

$11.6 \mathrm{~mm} \mathrm{month}^{-1}$. For the dry season, in the original model, the monthly Mean Error ranges from 10 to $17 \mathrm{~mm} \mathrm{month}^{-1}$, depending on different precipitation forcing. For the same season, in the coupled model, the monthly Mean Error's range is reduced to $2.2-3.4 \mathrm{~mm} \mathrm{month}^{-1}$. The new modelling scheme, by offering increased accuracy of evapotranspiration estimations, is an important step towards a better understanding of the two-way crops-atmosphere interactions.

\section{Introduction}

In recent years, much progress has been made in developing sophisticated Land Surface Models (LSMs), which are able to represent biophysical and hydrological processes of the land surface as well as their interaction with the atmosphere. However, one of the significant problems remaining to be addressed is the adequate representation of evapotranspiration (ET), which is the primary source of water transport from the land surface to the atmosphere.

Land-surface processes are intrinsically coupled with the atmosphere; changes in climate factors affect the vegetation dynamics and vice versa. Nowadays, it is common practice that LSMs are driven with prescribed vegetation dynamics. Vegetation parameters such us Leaf Area Index (LAI), root depth and canopy height are obtained offline and they either remain constant throughout the entire simulation period or can vary temporally and/or spatially depending on data availability prior to the simulation. However, such a simplified approach is expected to have a negative impact on the LSM's performance by affecting the simulated ET fluxes and 
ultimately obstructing weather and climate predictions and assessment of their impact on water resources.

This is especially the case in the Ganges Basin, a region which experiences monsoon flooding almost every year (e.g. the summer 2013 floods over northern India). In that region, the need for better predictions of the water resources regime and understanding of the land-surface-atmosphere interactions is very important. Recent studies have shown that there is evidence of strong coupling between the land surface (soil moisture) and atmosphere (precipitation). In the simplest sense, changes in near-surface soil moisture alter the partitioning between sensible and latent heat fluxes at the surface, affect stomatal conductance in vegetation, and are altering properties of the boundary layer. High evaporation linked to croplands and irrigation systems causes increased humidity and reduced temperatures near the surface followed by lower actual and potential evaporation. These changes can lead to local feedbacks in cloud formation and convection. Local feedbacks on convection have already been observed elsewhere in the tropics (e.g. in the Sahel, Taylor and Ellis, 2006). However, feedbacks may apply also on larger spatiotemporal scales. Much evidence already suggests that landsurface conditions in the Indo-Gangetic Plains are coupled to precipitation patterns. In early modelling experiments, Meehl (1994) showed the influence of the land surface on the Asian monsoon through changes in soil moisture and precipitation. More recently, several studies of the Global Land-Atmosphere Coupling Experiment (GLACE: Koster et al., 2004, 2006; Guo et al., 2006; Seneviratne et al., 2006), based on an ensemble of 12 atmospheric general circulation models, identified northern India as one of five global hotspots of land-atmosphere coupling strength during the boreal summer. This is also consistent with evidence of soil moisture feedbacks enhancing monsoon variability in West Africa (Lavender et al., 2010). Turner and Annamalai (2012) identify the South Asian monsoon as a fully coupled oceanland-atmosphere while previous studies found that croplands play an important role in determining the local climate. $\mathrm{Kr}-$ ishna Kumar et al. (2004) found strong linkages between Indian monsoon rainfall variations and Indian crop yield. Further, Osborne et al. (2009) showed that there is a strong feedback of crops to the climate of seasonally arid climates. In the humid tropical regions (such as India), inter-annually varying crops were found to alter the mean climate. Therefore, there is added complexity to the classical theory supporting that the strength of the Indian monsoon system is a consequence of the land-sea temperature contrast.

To overcome this limitation, several recent studies achieved dynamical coupling of LSMs, climate or hydrological models with crop growth models (Boegh et al., 2004; Mo et al., 2005; Pauwels et al., 2007; Osborne et al., 2007; Maruyama and Kuwagata, 2010; Lei et al., 2010; Li et al., 2013). Efforts have also been made to include dynamic vegetation representation in LSMs (Cox et al., 2000; Dai, 2003; Van den Hoof et al., 2011) and hydrologic models (Calvet et al., 1998; Calvet and Soussana, 2001; Li et al., 2011). The novelty of our approach lies in the combination of the following points: (1) we attempt to quantify the potential error in ET estimations of LSMs with no dynamic vegetation, by comparing the pro-coupling and post-coupling modelling results; most of the previous studies did not show modelling results before the coupling. This allows us to test the sensitivity of an LSM with regard to the dynamics of the vegetation cover. (2) The large spatial scale of the application - most of the past studies are focused on small scales, or even point scales, and validated their results against flux tower sites. The extent of the agricultural areas such as the Ganges Basin, and the lack of in situ measurements, make it a very challenging research environment. (3) The specific focus on impact on evaporative flux, contrasting to most coupling studies that focus on LAI, crop yield and/or soil moisture fluxes.

This research aims to propose a fully coupled land-surface crop-growth model in order to improve representation of vegetation dynamics and simulation of fluxes over croplands. The variations between ET fluxes from an LSM with and without dynamic crop growth are calculated as an indicator of potential uncertainties in the model estimates. The new modelling scheme will allow for further examination of the role of land-surface properties on atmospheric conditions, including human activities such as irrigation practices. The following hypothesis drives the research: "Accounting for dynamic crop growth in an LSM will significantly improve the representation of soil and land-surface processes and will give us insights in the sensitivity of ET fluxes in complex agricultural regions such as the Ganges Basin".

We apply the LSM JULES (Best et al., 2011; Clark et al., 2011) in order to investigate the impact of inter-seasonal land cover changes in the ET fluxes of the Upper Ganges (UG) River basin in India. However, JULES in its current version does not simulate crop growth. Instead $\mathrm{C}_{3}$ grass is typically used as proxy for annual crops. This simplified approach has the disadvantage that transient parameters such as LAI are kept constant throughout long periods. Additionally, differences in structural and physiological characteristics between natural vegetation and crops, (i.e. albedo, surface roughness, rooting depth, leaf area, canopy resistance), impact the physical properties of the land surface and the bio-geochemical cycles, causing feedbacks to the climate (Van den Hoof et al., 2011). Given that the larger part $(60 \%)$ of the UG Basin is occupied by agriculture, such simplification $\left(\mathrm{C}_{3}\right.$ grass as a proxy for annual crops) is expected to lead to errors in the model's results.

In order to overcome this problem, JULES was coupled with the crop growth model InfoCrop (Aggarwal et al., 2006a). This coupled system will allow the consistent variation of variables during the simulation period. The model was parametrized for the two main crops of the UG Basin (wheat and rice) to capture well the inter-annual variations in landsurface processes with subroutines that represent crop growth using a daily time step from sowing to maturity. A crop 

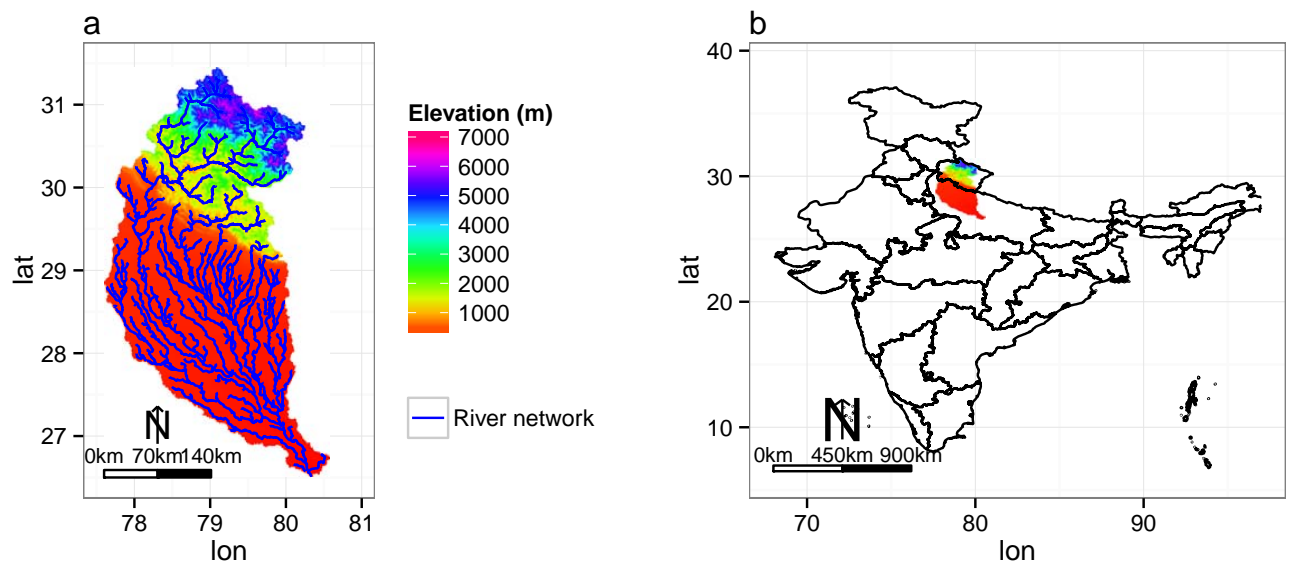

Figure 1. (a): Digital Elevation Model (DEM) of the UG Basin showing the ranges of the elevations (altitude in metres) and the river network. (b): location map of the study area in north India.

calendar based on available data was developed and added to the coupled system, informing it for the crop type, sowing and harvest dates and fallow land periods, allowing for two cropping seasons per year. The sensitivity of JULES with regard to the dynamics of the vegetation cover is tested. The discrepancy between the original and the coupled modelling schemes gives an approximation of the uncertainty in the ET results derived by an LSM with no dynamic vegetation.

This study attempts to quantify the potential error in surface flux estimations of global LSMs because of not taking into account dynamic crop development. The dynamic coupling of an LSM with a crop growth model is expected to improve the modelling of ET fluxes, whilst having a direct impact on climate factors. This will facilitate the understanding of land-atmosphere interactions and essentially lead to improved weather and climate predictions as well as a more adequate interpretation of their impacts on water resources.

\section{Study area and data description}

In recent decades the Indian subcontinent has undergone substantial environmental change. Agricultural land areas expanded to meet the demands of a rapidly increasing population and groundwater extractions were intensified, leading to an alarming drop in the water table levels (Tsarouchi et al., 2014). The North Indian plains are amongst the most densely populated and intensively cultivated areas in the world. More than 400 million people depend on monsoon rainfall for their livelihood.

The study area, located in northern India, is part of the UG Basin, which corresponds to the upper main branch of the River Ganges and covers an area of $87000 \mathrm{~km}^{2}$ (Fig. 1). The River Ganges originates in the Himalayas and when it reaches the plains, it becomes subject to a vast irrigation demand as $60 \%$ of the basin is occupied by agriculture (Tsarouchi et al., 2014). As the focus of our study is

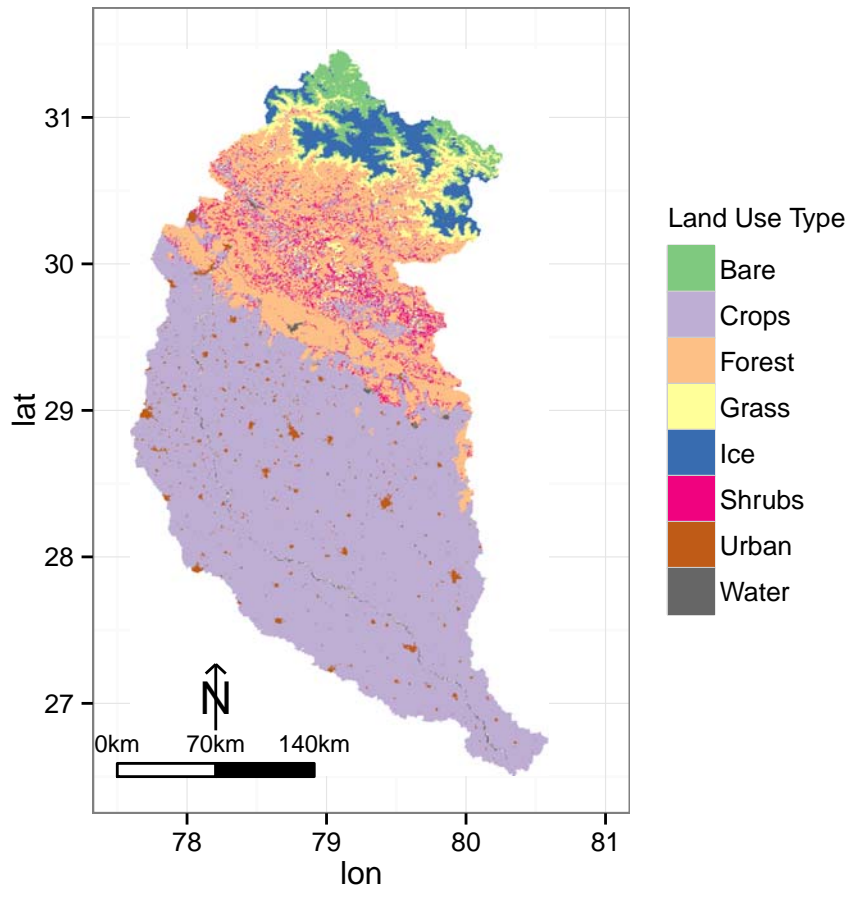

Figure 2. Land cover map for year 2000, as developed by Tsarouchi et al. (2014).

on improving crop growth simulation, we decided to apply our model only in the areas occupied by agriculture. Hence, from now on as study area we refer to the crop-covered areas of the UG Basin, as shown in Fig. 2. The two main crops grown in that region are wheat and rice. In Uttar Pradesh (i.e. the district the study area belongs to), rice is predominantly rain fed and depends largely on the monsoon season rains from June to September (USDA-I, 2013). However, the intensive wheat/rice crop rotation in the area is responsible for 
Table 1. JULES-Info parameters for wheat and rice.

\begin{tabular}{|c|c|c|c|}
\hline Parameters & Wheat & Rice & Units \\
\hline Optimal temperature & 25 & 30 & ${ }^{\circ} \mathrm{C}$ \\
\hline Maximum temperature & 40 & 42 & ${ }^{\circ} \mathrm{C}$ \\
\hline Base temperature for sowing to germination & 3.6 & 7.6 & ${ }^{\circ} \mathrm{C}$ \\
\hline Thermal time for sowing to germination & 70 & 50 & ${ }^{\circ} \mathrm{C}$ days \\
\hline Base temperature for germination to $50 \%$ flowering & 4.5 & 10 & ${ }^{\circ} \mathrm{C}$ \\
\hline Thermal time for germination to $50 \%$ flowering & 800 & 1650 & ${ }^{\circ} \mathrm{C}$ days \\
\hline Base temperature for $50 \%$ flowering to maturity & 7.5 & 10 & ${ }^{\circ} \mathrm{C}$ \\
\hline Thermal time for $50 \%$ flowering to maturity & 373 & 430 & ${ }^{\circ} \mathrm{C}$ days \\
\hline Relative growth rate of leaf area & 0.005 & 0.009 & $\left({ }^{\circ} \mathrm{Cd}\right)^{-1}$ \\
\hline Specific leaf area & 0.0020 & 0.0022 & Ha leaf $\mathrm{kg}^{-1}$ leaf \\
\hline Root extension growth rate & 25 & 12 & $\mathrm{~mm} \mathrm{~d}^{-1}$ \\
\hline Maximum root depth & 2000 & 400 & $\mathrm{~mm}$ \\
\hline $\begin{array}{l}\text { Index of storage organs formation: Slope of storage } \\
\text { organ number } \mathrm{m}^{-2} \text { to dry matter during storage formation }\end{array}$ & 30000 & 56000 & No $(m)^{-2}(\mathrm{~kg} \text { dry matter })^{-1}$ \\
\hline Potential weight of the storage organs & 42 & 22 & $\operatorname{mg}(\text { storage organ })^{-1}$ \\
\hline Nitrogen content of storage organ & 2 & 1.4 & $\%$ \\
\hline
\end{tabular}

soil degradation which causes drops in the water table levels in some areas and water logging in others (USDA-I, 2013).

Meteorological data required for the modelling experiments include precipitation, incoming short-wave and longwave radiation, surface pressure, temperature, specific humidity and wind speed. The different meteorological data sets used to drive the models are summarized in Table 2. All data sets were further rescaled to the spatial scale of the JULES implementation, i.e. $0.1^{\circ} \times 0.1^{\circ}$.

The land cover representation is based on high-resolution land cover maps for northern India, developed by the authors (Tsarouchi et al., 2014) and based on Landsat satellite imagery. Figure 2 shows the map developed for year 2000. The temporal changes in land cover over the period 20002008 are also presented in the same study by Tsarouchi et al. (2014).

Soil parameters were created by the UK Met Office Unified Model Central Ancillary Program (UM-CAP) at the model resolution, based on soil texture maps from the Harmonized World Soil Database (FAO, 2009).

Due to lack of ET observations within our study area, we decided to use the MODIS (Mu et al., 2007, 2011) and the LandFlux-EVAL (Mueller et al., 2013) ET data sets as reference for evaluating our models. The MODIS (MOD16) global ET data set was developed as part of the NASA/EOS project to estimate global terrestrial ET by using satellite remote sensing data. The data set covers the time period 20002010 in a spatial resolution of $1 \mathrm{~km}$. It was developed using the ET algorithm of Mu et al. (2011), improved over a previous $\mathrm{Mu}$ et al. (2007) paper. The algorithm is based on the Penman-Monteith (Penman, 1948) approach. The input data used to develop the MODIS ET product include: MODIS land cover type (MOD12Q1) (Friedl et al., 2002); MODIS FPAR/LAI (MOD15A2) (Myneni et al., 2002); MODIS albedo (Lucht et al., 2000; Jin et al., 2003); and NASA's MERRA GMAO (GEOS-5) daily meteorological reanalysis data from 2000 to 2010 . In order to make the comparison of our model outputs with the MODIS product as meaningful as possible: (a) we made sure that our study area corresponds to $100 \%$ agricultural area in the MODIS land cover maps and (b) we ran a set of simulations with the same meteorological reanalysis data set that was used for the development of MODIS ET. In the original JULES, LAI remained constant within the entire simulation whereas in the coupled model, LAI was calculated on a daily basis from the crop model and passed into JULES (more details regarding the coupling process are available in the following Sect. 3.3).

The LandFlux-EVAL data set was generated as part of the LandFlux-EVAL initiative of the GEWEX Data and Assessment Panel (GDAP). Mueller et al. (2013) evaluated and compared existing land ET products and generated global merged benchmark products based on the analysis of the already existing data sets. The product covers the periods of 1989-1995 and 1989-2005, at a monthly timescale and a $1^{\circ}$ resolution. In this study we used the 1989-2005 period data set which is based on a total of 14 data sets. In the individual data sets, ET is derived from satellite and/or in situ observations or calculated via LSMs driven with observationsbased forcing or output from atmospheric reanalysis models (Mueller et al., 2013).

Lastly, the MODIS LAI (MOD15A2) product (Myneni et al., 2002) was used to evaluate the LAI as calculated from the coupled system. 


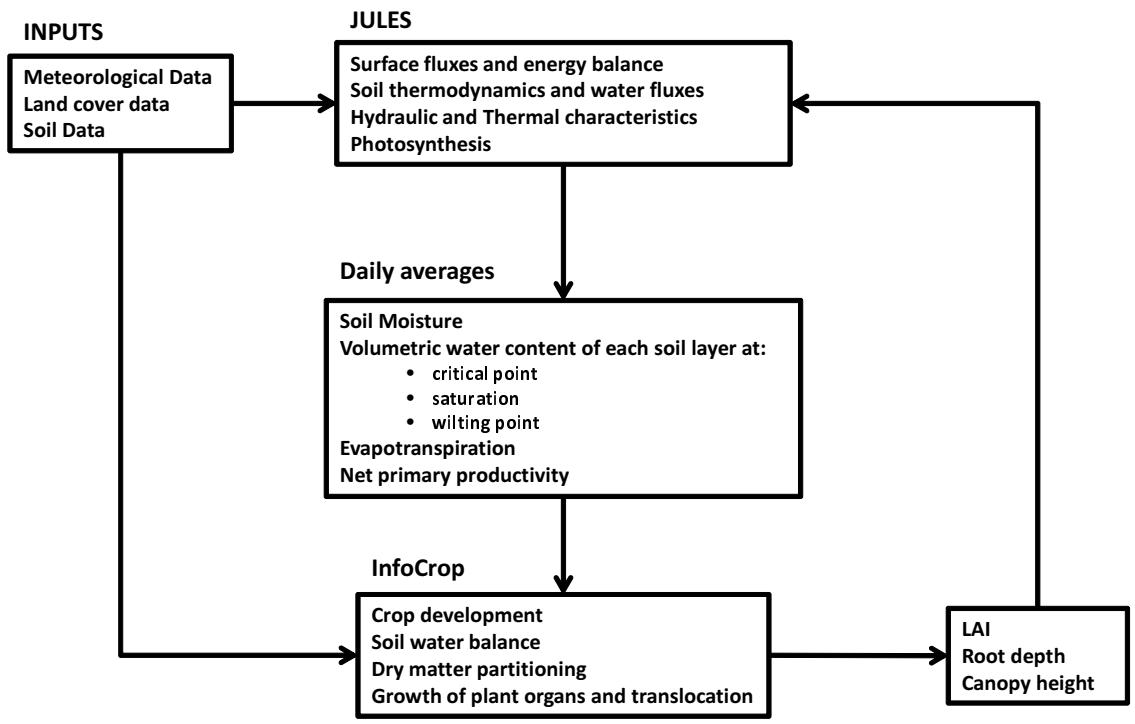

Figure 3. Flow chart of the coupling system.

\section{Model description}

\subsection{JULES land-surface model}

JULES, the Joint UK Land Environment Simulator (Best et al., 2011; Clark et al., 2011) is a physics-based model which is used as the land-surface scheme of the UK Met Office's Unified Modelling system.

The model partitions precipitation into canopy interception and throughfall. In the default runoff scheme, surface runoff is generated based on Hortonian Infiltration and saturation excess mechanisms. Surface heterogeneity within JULES is represented by the tile approach (Essery et al., 2003). The surface of each grid-box comprises fractions of nine different surface types; five vegetated Plant Functional Types (PFTs): broad-leaf trees, needle-leaf trees, $\mathrm{C}_{3}$ grasses, $\mathrm{C}_{4}$ grasses and shrubs and four non-vegetated: urban, water, bare soil and ice. For each surface type of the grid-box, a separate surface energy balance is solved, and a weighted average is calculated from the individual surface fluxes for each grid-box. In the subsurface, the soil column is divided into four layers, which have a thickness of $0.1,0.25,0.65$, and $2 \mathrm{~m}$ respectively, going from the top to the bottom. The DarcyRichards equation (Richards, 1931) is solved using finite difference approximation, to calculate water movement through the soil. Subsurface runoff is represented as free drainage from the deepest soil layer. The soil water retention characteristics follow the relationships of van Genuchten (1980). A structural limitation of the current JULES version is that there is no subsurface heterogeneity at the sub-grid scale, in contrast to on the surface.

The input meteorological data requirements are time series of incoming shortwave and longwave radiation, precipitation, temperature, specific humidity, wind speed and surface pressure. They are used in a full energy balance equation that consists of radiation, sensible heat, latent heat, canopy heat and ground surface heat components (Zulkafli et al., 2013a).

Vegetation biophysical processes, such as photosynthesis, stomatal conductance and transpiration, dynamically interact with hydrological and land-atmosphere energy exchange processes through an integrated coupling. The PenmanMonteith (Penman, 1948) approach is used to estimate potential evaporation. Canopy evaporation (interception storage) is assumed to occur at the potential rate, while plant transpiration from root water uptake from all four soil layers (vegetated areas) and bare soil evaporation from the top soil layer are restricted by stomatal resistance and the soil moisture state, respectively (Zulkafli et al., 2013a). The stomatal resistance is also responsible for the regulation of $\mathrm{CO}_{2} \mathrm{ex}-$ change between plants and the atmosphere (Cox et al., 1998).

Because the model does not simulate crop growth, crop areas are treated as natural grass (Van den Hoof et al., 2011). Vegetation parameters such us Leaf Area Index (LAI), root depth and canopy height are obtained off-line and they either remain constant throughout the entire simulation period or can vary temporally and/or spatially (apart from the root depth which cannot vary spatially) depending on data availability prior to the simulation. Root depth and density determine the ability of vegetation to access moisture at each level in the soil (Best et al., 2011). LAI, which illustrates the density of the leaves, is an important parameter as it contributes to the latent heat flux calculation by determining the relative fractions of ET and bare soil evaporation in vegetative surfaces (Best et al., 2011). Canopy coverage, which is a function of LAI, influences the albedo calculation. In addition, for vegetated surfaces, the maximum amount of water that can be held by the canopy is a linear function of LAI. 
Table 2. Meteorological data used to drive the models.

\begin{tabular}{llllll}
\hline Variable & Name & Resolution & Time step & Time domain & Reference \\
\hline Precipitation & TRMM 3B42 v7 & $0.25^{\circ} \times 0.25^{\circ}$ & 3 hourly & $2000-2008$ & $\begin{array}{l}\text { Huffman and Bolvin (2013); } \\
\text { Zulkafli et al. (2013b) } \\
\text { GMAO (2004) }\end{array}$ \\
& MERRA GMAO & $0.50^{\circ} \times 0.67^{\circ}$ & 3 hourly & $2000-2008$ & GMeffield et al. (2006) \\
\hline $\begin{array}{l}\text { Radiation, surface temperature, } \\
\text { surface pressure, specific humidity, } \\
\text { wind speed }\end{array}$ & NCEP $^{\mathrm{b}}$ & $1.00^{\circ} \times 1.00^{\circ}$ & 3 hourly & $2000-2008$ & ShRA GMAO \\
$0.50^{\circ} \times 0.67^{\circ}$ & 3 hourly & $2000-2008$ & GMAO (2004) \\
\hline
\end{tabular}

a The reanalysis data from NASA's Global Modeling and Assimilation Office (MERRA GMAO, GEOS-5) was used for the development of the MODIS ET data set (Mu et al., 2011) and was chosen in our study to facilitate ET comparison between our models and the MODIS ET product. ${ }^{\mathrm{b}}$ The post-processed product developed by Sheffield et al. (2006) is the first-generation NCEP (US National Center of Environmental Predictions, Kalnay et al., 1996) climate reanalysis product merged with ground truth data.

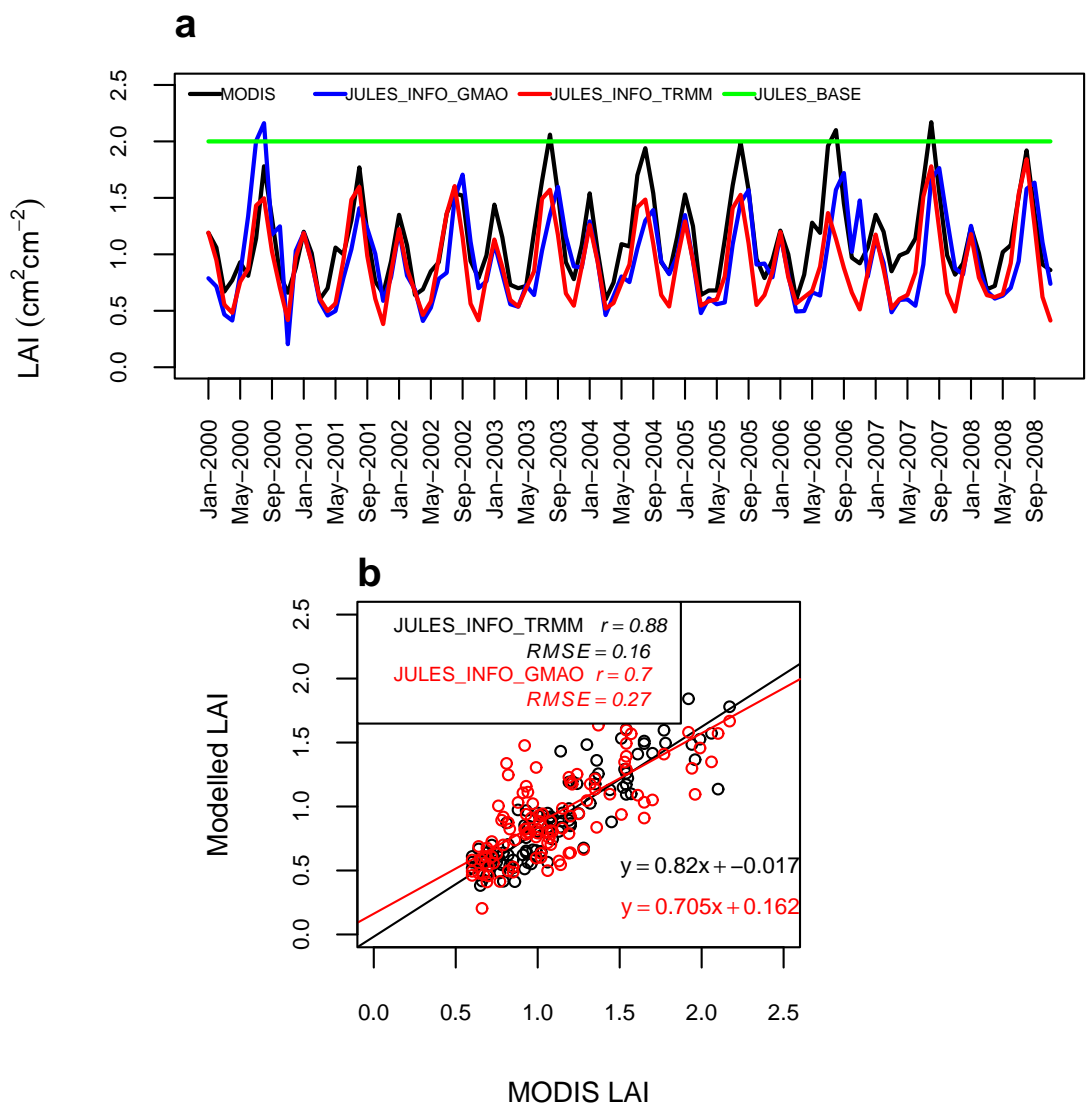

Figure 4. (a) The MODIS LAI is compared with the JULES-Info (forced by the two different meteorological data sets) modelled LAI. JULES-base was run with its default LAI value set to 2 for crops. (b) Performance scores JULES-Info with TRMM and GMAO forcing data sets. The results show that the modelled LAI matches the observed MODIS LAI well. The two peaks per year represent the two cropping seasons as specified by the crop calendar.

Thus, a simplified approach that does not allow for constant evolving of those parameters is expected to have a negative impact in the model's performance.

In JULES, the canopy capacity to hold water $C_{m}\left(\mathrm{~kg} \mathrm{~m}^{-2}\right)$ is computed as

$C_{m}=0.5+0.05 \mathrm{LAI}$,

where $0.5 \mathrm{~kg} \mathrm{~m}^{-2}$ is the minimum water interception due to puddling of water on the soil surface and/or interception by leafless plants (through branches and trunk). In the coupled model, this equation has been modified (see Eq. 3) to match the canopy capacity as calculated by InfoCrop and to enhance the dependency of canopy interception to LAI (as has also been suggested by Van den Hoof et al., 2013). For a more detailed description of the model see Best et al. (2011). 

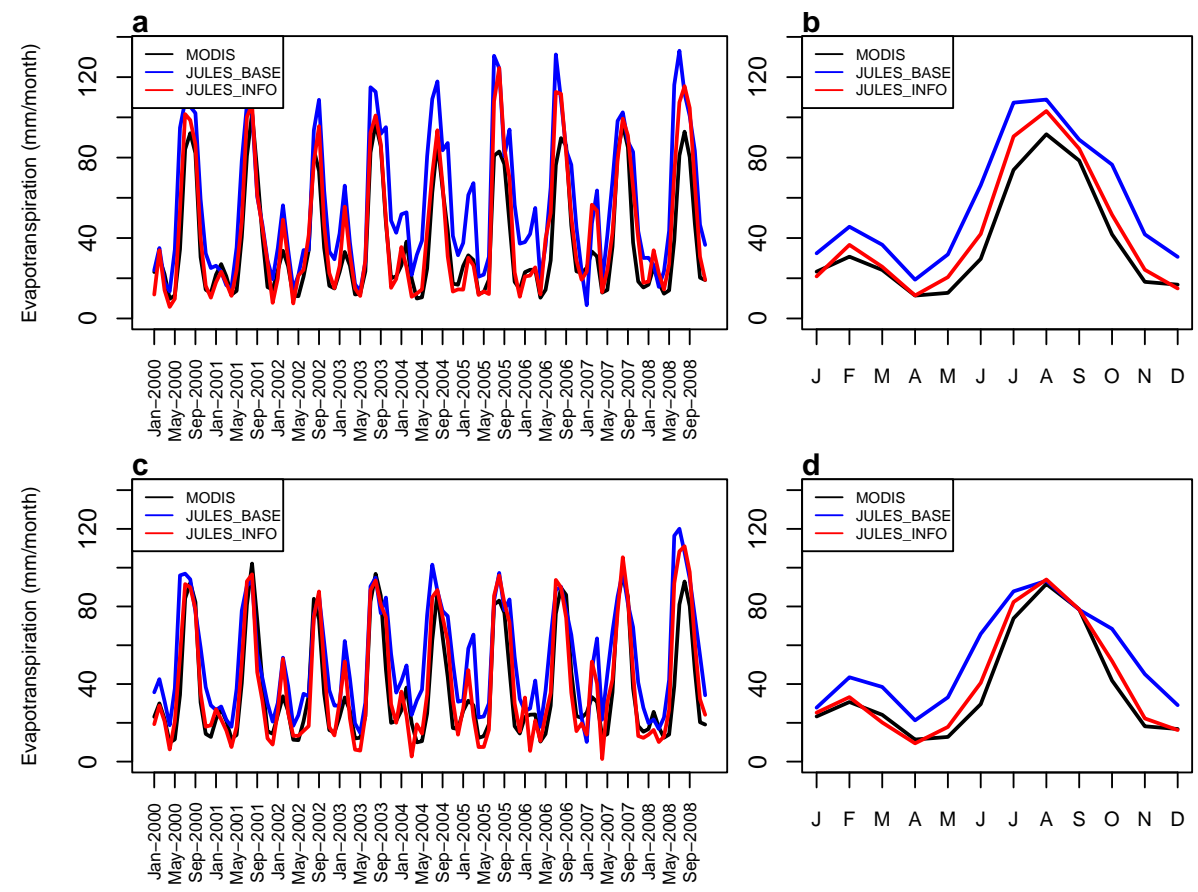

Figure 5. Comparison between MODIS ET and simulated ET by the two models: JULES-base and JULES-Info: (a) and (b) are with GMAO forcing data and (c) and (d) with TRMM and NCEP forcing data. The right-hand plots (b, d) show the mean seasonal cycle of evapotranspiration (units: $\mathrm{mm} \mathrm{month}^{-1}$ ) for each of the models, showing the mean bias per month.

\subsection{Crop growth model}

The functions used to calculate crop development, crop growth, LAI and root depth are based on InfoCrop (Aggarwal et al., 2006a), a crop growth model which has been parametrized for Indian soils and crop systems. The model simulates crop development, photosynthesis, dry matter production and its partitioning, leaf area growth, ET etc. in response to the effects of weather, soil properties, sowing dates and crop physiology. Similarly to JULES, the PenmanMonteith (Penman, 1948) approach is used to calculate potential ET. In the subsurface, the soil column is divided into three layers and a tipping bucket approach is followed for the soil water balance. Transpiration is calculated as a function of the water availability in the soil, represented by water stress factors for each soil layer. The values of water stress factors range between 0 and 1 . The water contents at wilting point, critical point and saturation as well as the water content in each soil layer are required to calculate the water stress factors. Total water uptake is calculated based on the water stress factors of individual soil layers. Photosynthesis is highly sensitive to water stress. Under insufficient water supply conditions, $\mathrm{CO}_{2}$ assimilation rate (photosynthesis) and stomatal conductance decrease rapidly below the potential rates.

The major photosynthesizing organs are leafs. The calculation of the photosynthetically active radiation absorbed by the surface area of green leafs is highly dependent on the
LAI. This highlights that for optimized crop growth modelling, the most essential requirement is a correct simulation of the time course of LAI. After crop emergence, the main parameters affecting leaf area expansion are temperature and light intensity. In the early stage of juvenile growth, the increase of leaf area over time is approximately exponential. During later development stages, shading from other plant branches might restrict the leaf area expansion. Apart from shading, the senescence of leaves in InfoCrop is also dependent on ageing, nitrogen mobilization, temperature, water stress and death due to pests and diseases (Aggarwal et al., 2006a).

In InfoCrop, canopy interception is assumed to be equivalent to $25 \%$ of the value of LAI at any given time (Penning de Vries et al., 1989).

Root depth extension rate is affected by soil water stress, soil bulk density, potential maximum rooting depth and temperature (low temperatures reduce growth). The maximum rooting depth varies as a function of thermal time to anthesis; the longer the crop duration the deeper the roots would go in the soil. If the roots reach a soil layer with moisture content at or below wilting point, root growth is interrupted. Moisture content near wilting point causes a very low water uptake rate and that leads to insufficient energy production for maintenance respiration by photosynthesis. In such case the crop dies. Otherwise, root growth continues until a cropspecific development stage. 

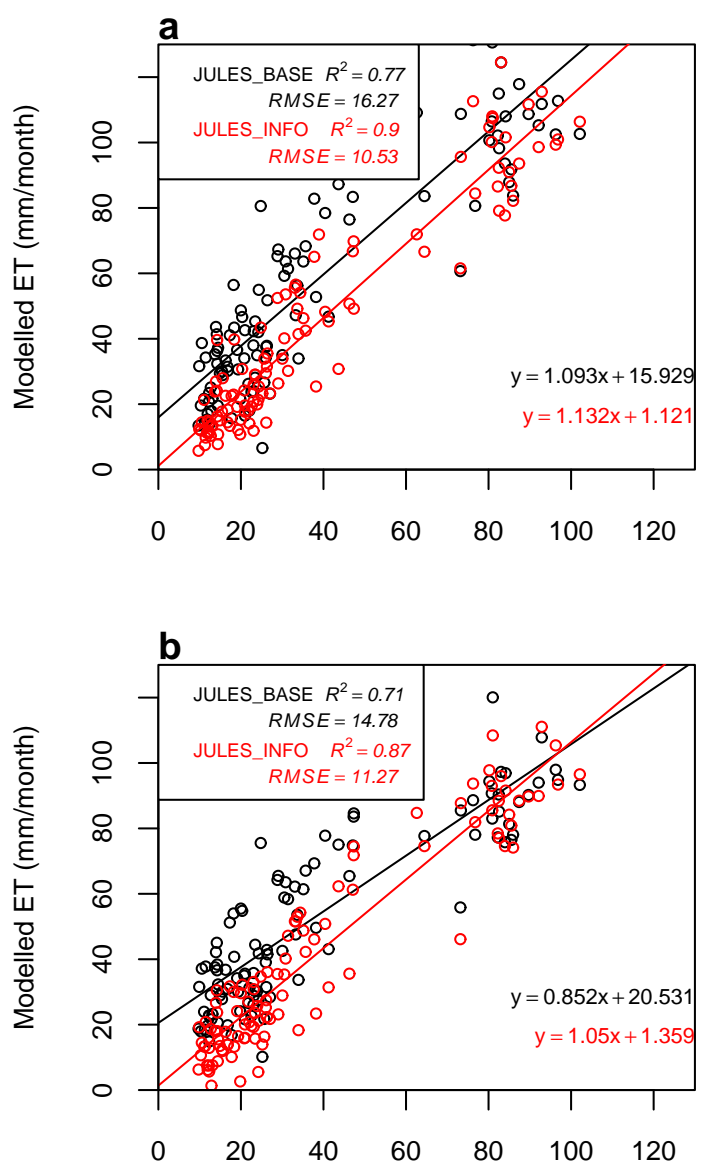

MODIS ET (mm/month)

Figure 6. Performance scores of the two models (JULES-base and JULES-Info) in comparison with MODIS ET: (a) is with GMAO forcing data and (b) with TRMM and NCEP forcing data.

The model separates between three development stages: (a) seedling emergence, (b) anthesis and (c) maturity. Under temperate climate conditions, the development rate is mainly affected by temperature.

For a more detailed description of the model see Aggarwal et al. (2006a).

\subsection{Model coupling}

The distributed version of JULES was run with a resolution of $0.1^{\circ}$ and an hourly time step while InfoCrop was run at a daily time step. To ensure agreement in calculations, the same meteorological and soil data sets were used for both models.

In the coupled version, the full energy balance scheme of JULES was used to calculate water exchange between soil layers, land-atmosphere heat flux exchange, ET etc. in each time step. Every 24 time steps of JULES (i.e. 1 day), the following values (daily averaged) were passed to the crop model: moisture content, ET, volumetric water content at critical point, at saturation and at wilting point (of each soil layer), plant net photosynthetic uptake. The crop model then simulated the agricultural practices, crop growth, dry matter production and partitioning etc. and provided daily values of LAI, root depth and canopy height. These values were returned to JULES which continued to the next day of the simulation (see Fig. 3 for a flow chart of the coupled system). The coupled JULES-InfoCrop model will be hereafter referred to as JULES-Info and the original JULES model will be hereafter referred to as JULES-base.

Based on a crop calendar review (Agropedia, 2013; NFSM, 2013; USDA-I, 2013; FAO, 2013; ICAR, 2013) we concluded that the main crops grown in our study area (district of Uttar Pradesh) are rice during the summer months (July-October) and wheat during the winter months (October-March). Therefore, the JULES-Info model was parametrized for those crops (following the parameters suggested by the developers of InfoCrop; Aggarwal et al., $2006 \mathrm{a}, \mathrm{b})$ under a two-crop rotation system and a crop calendar was added to the coupled model. Table 1 shows the different parameters used by JULES-Info for rice and wheat.

Canopy height is calculated based on Eq. (61) in Clark et al. (2011), where $W$ is the carbon content of the stems, calculated by the crop model.

In JULES-base, the $C_{3}$ photosynthesis model (Collatz et al., 1991) is a function of the maximum rate of carboxylation of Rubisco, $V_{\mathrm{m}}$ (see Cox, 2001, Eqs. 43, 45 and 51). $V_{\mathrm{m}}$ is a function of the potential maximum carboxylation rate at $25^{\circ} \mathrm{C}, V_{\max }$. For $\mathrm{C}_{3}$, in JULES-base, $V_{\max }=0.0008 \times n_{1}$, where $n_{1}$ is the leaf nitrogen concentration. In the JULESInfo model we made the following adaptation:

$V_{\max }= \begin{cases}0.0008 \times n_{1}, & \text { wheat } \\ 0.00036 \times n_{1}, & \text { rice }\end{cases}$

since $V_{\max }$ of Rubisco in rice is $45 \%$ lower than that of wheat (Sheehy et al., 2000).

In JULES-base, the surface infiltration rate $K$ is equal to $\beta_{\mathrm{S}} \times K_{\mathrm{S}}$, where $K_{\mathrm{S}}$ is the soil saturated hydrological conductivity and $\beta_{\mathrm{s}}$ an enhancement factor (Best et al., 2011). The default value of $\beta_{\mathrm{s}}$ for $\mathrm{C}_{3}$ grass in JULES-base is 2 . For the other PFTs, $\beta_{\mathrm{s}}$ is 4 for trees and 2 for $\mathrm{C}_{4}$ grass and shrubs. However, and as also suggested by Van den Hoof et al. (2013), no justification can be found for different $\beta_{\mathrm{s}}$ values between different PFTs, therefore, in JULES-Info the value of $\beta_{\mathrm{S}}$ was set equal to 1 for all PFTs.

In JULES-Info, canopy capacity is calculated through an adaptation of the formulae used in JULES-base and InfoCrop, as follows:

$C_{m}=0.05+0.25 \mathrm{LAI}$.

This adapted formulation is more in line with the equation suggested by Van den Hoof et al. (2013), after taking into account what is used in other LSMs and review papers. The 

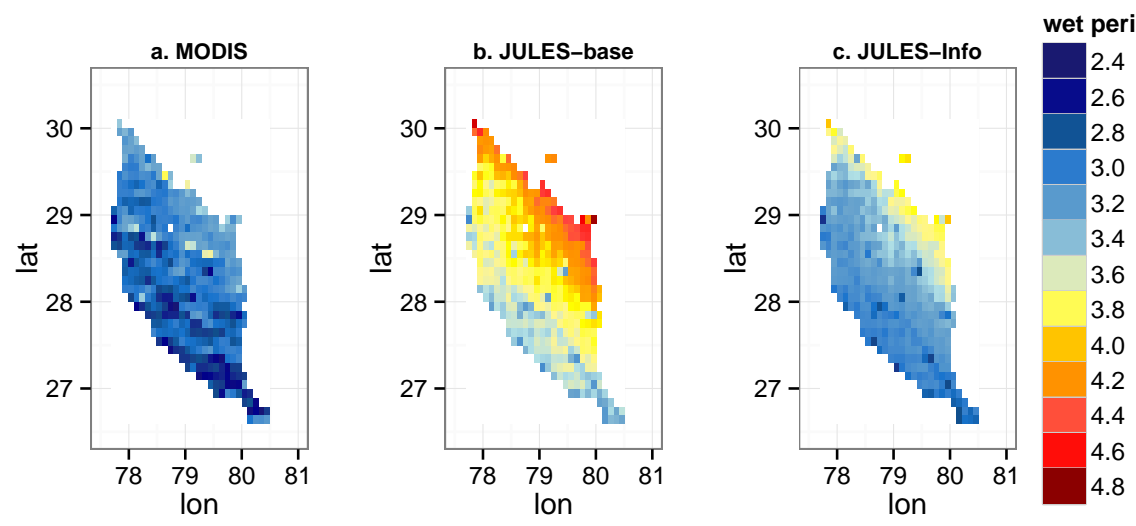

Figure 7. Spatial comparison of the modelled ET with the MODIS product, for agricultural areas, averaged over the wet (June-September) months of years 2000-2008.
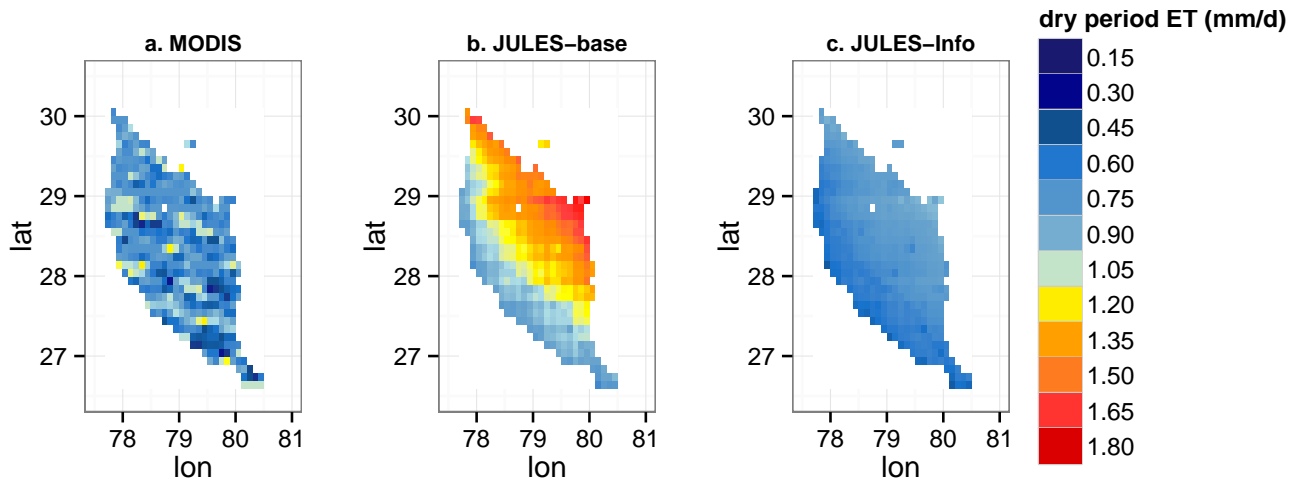

Figure 8. Spatial comparison of the modelled ET with the MODIS product, for agricultural areas, averaged over the dry (October-May) months of years 2000-2008.

new formula is expected to increase canopy capacity dependence to LAI (Van den Hoof et al., 2013).

InfoCrop calculates dry matter production as a function of the Radiation Use Efficiency (RUE) (Aggarwal et al., 2006a). In contrast, JULES-base follows a biochemical approach which links the calculation of the leaf level stomatal conductance to the net photosynthetic uptake via a $\mathrm{CO}_{2}$ diffusion equation (Best et al., 2011). Because in the coupled scheme we maintain the ET calculation mechanism of JULES-base, it is sensible that the photosynthesis is calculated from JULES-base as well. In JULES-Info, the dry matter production is no longer calculated as a function of RUE (according to InfoCrop) but is based on the net primary productivity (structural dry matter) as calculated by the LSM's photosynthesis scheme.

Irrigation in the coupled model has not been included yet and possible impacts of this simplification are discussed in Sect. 4 .

\subsection{Model experiments}

The simulations were performed over the study area for a period of 9 years between 2000 and 2008 to coincide with the periods of available data from NCEP, TRMM, GMAO and MODIS.

Four different model simulations were performed: (a) JULES-base driven with the GMAO meteorological data set; (b) JULES-base driven with TRMM precipitation data and the post-processed NCEP data set for the rest meteorological variables; (c) JULES-Info driven with the GMAO meteorological data set; (d) JULES-Info driven with TRMM precipitation data and the post-processed NCEP data set for the rest of the meteorological variables.

The JULES-base simulations were run with $\mathrm{C}_{3}$ crop parametrization, where the vegetation parameters were adapted to crops and have been used as a reference. The JULES-Info simulations were run with dynamic crop growth parametrization, where its interactions with the environment were simulated.

To quantify the uncertainty in the ET results derived by an LSM with no dynamic vegetation and the impact of the applied changes, LAI and ET output values were validated against the equivalent MODIS and LandFlux-EVAL products. Performance scores tested include the correlation 

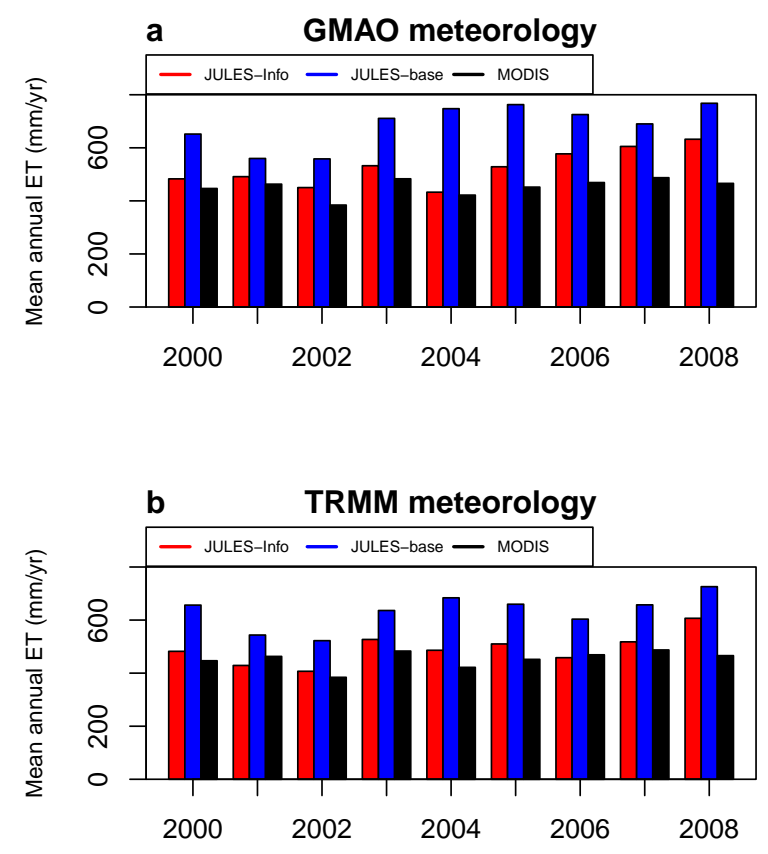

Figure 9. Comparison of the mean annual ET within our study area, as derived from JULES-base, JULES-Info and MODIS.

coefficient $(r)$, the coefficient of determination $\left(R^{2}\right)$, the RMSE and the Mean Error.

\section{Results}

The sensitivity of the LSM JULES was evaluated with respect to the daily and seasonal dynamics of the vegetation cover in the study area. When the model runs without a dynamic vegetation growth scheme, it assumes $100 \%$ agricultural coverage throughout the entire simulation period. There is no information about seedling, emergence or harvesting dates, nor about the duration of fallow land periods between different cropping seasons. In addition it is assumed that the cultivated crop is a generic $\mathrm{C}_{3}$ grass. However, when the model runs coupled with the crop growth model (and hence dynamic vegetation growth is included), the seedling, emergence and harvesting dates are defined, fallow land periods are included in the simulation and a two-crop rotation scheme (wheat vs. rice) is introduced, with different parametrization for each crop (Table 1).

The MODIS LAI is compared with the JULES-Info (forced by the two different meteorological data sets) modelled LAI as shown in Fig. 4a. JULES-base was run with its default LAI value set to 2 for crops. The results show that the modelled LAI matches the observed MODIS LAI well. The correlation coefficients for TRMM and GMAO forcing data sets are $r=0.88$ and $r=0.70$ respectively and the RMSE values are RMSE $=0.16$ and $\mathrm{RMSE}=0.27$ respectively (Fig. 4b). The two peaks per year represent the two cropping seasons as specified by the crop calendar. The re- duced LAI values as calculated by the JULES-Info model in comparison to the steady value of $\mathrm{LAI}=2$ used by the JULES-base model are reducing the canopy storage which is directly translated into a reduced canopy interception. This is expected to cause a decrease in the total ET estimation.

The ET results show that JULES is sensitive to the changes introduced after coupling it with the crop model. In the JULES-base version, ET fluxes are often higher in comparison to the JULES-Info version results (Figs. 5, 7 and 8). There is a significant difference especially when the dry and the fallow land periods are simulated. JULES-base is overestimating ET as it simulates a false land cover with $100 \%$ agriculture that indeed evaporates more than the bare soil does. Figure 5 shows that JULES-base, after the wet season peak in ET, reproduces a second lower peak in month October of years 2003-2005. However, JULES-Info in agreement with MODIS and LandFlux-EVAL (Fig. 12) does not reproduce that second peak. This behaviour of JULES-base is possibly related to a combination of precipitation and temperature patterns as well as the fact that it operates under a constant LAI of 2, whereas for JULES-Info, October is a month with very low LAI values (near 0.5 ), as it is the transition period between rice harvesting and wheat planting according to our crop calendar (Fig. 4a). In addition, JULES-Info matches better the MODIS and LandFlux-EVAL fluctuation and timing of the peak values. In both plots, the modelled by JULES-base ET is higher than the MODIS ET. JULESbase tends to overestimate ET mainly during the dry period because then the difference between the default LAI value of 2 and the actual LAI value of the growing crop (wheat) is larger. This is also clearly illustrated in Fig. 5b and d which show the mean seasonal cycle of ET(mm month ${ }^{-1}$ ) and give an approximation of the mean bias per month for each of the models. Similar trends have been observed by Blyth et al. (2010), who used surface energy flux measurements from 10 FLUXNET sites around the world that represented a range of climate conditions and biome types, and found that the JULES-base evaporation is higher than that observed; the same results were also found by Van den Hoof et al. (2011), who found that the JULES-base latent heat flux is overestimated over cropland in Europe. One possibility for this bias is an overestimation of canopy interception. Blyth et al. (2011), who applied a set of benchmark tests in order to quantify the performance of JULES, found indeed that the model is overestimating respiration and that if the evaporation is overestimated, then so is the photosynthesis. They suggest that these errors occur mainly due to the simple approach of using a fixed, predetermined LAI. Therefore and as expected, the more sophisticated approach of JULESInfo, which calculates LAI evolution on a daily basis, offers improved accuracy. The coupled model captures better the seasonal variability of ET. An overall decrease in the modelled ET (Figs. 5, 7 and 8) compared to MODIS ET is observed. $R^{2}$ values are significantly improved compared to the JULES-base equivalent values and RMSE values are reduced 

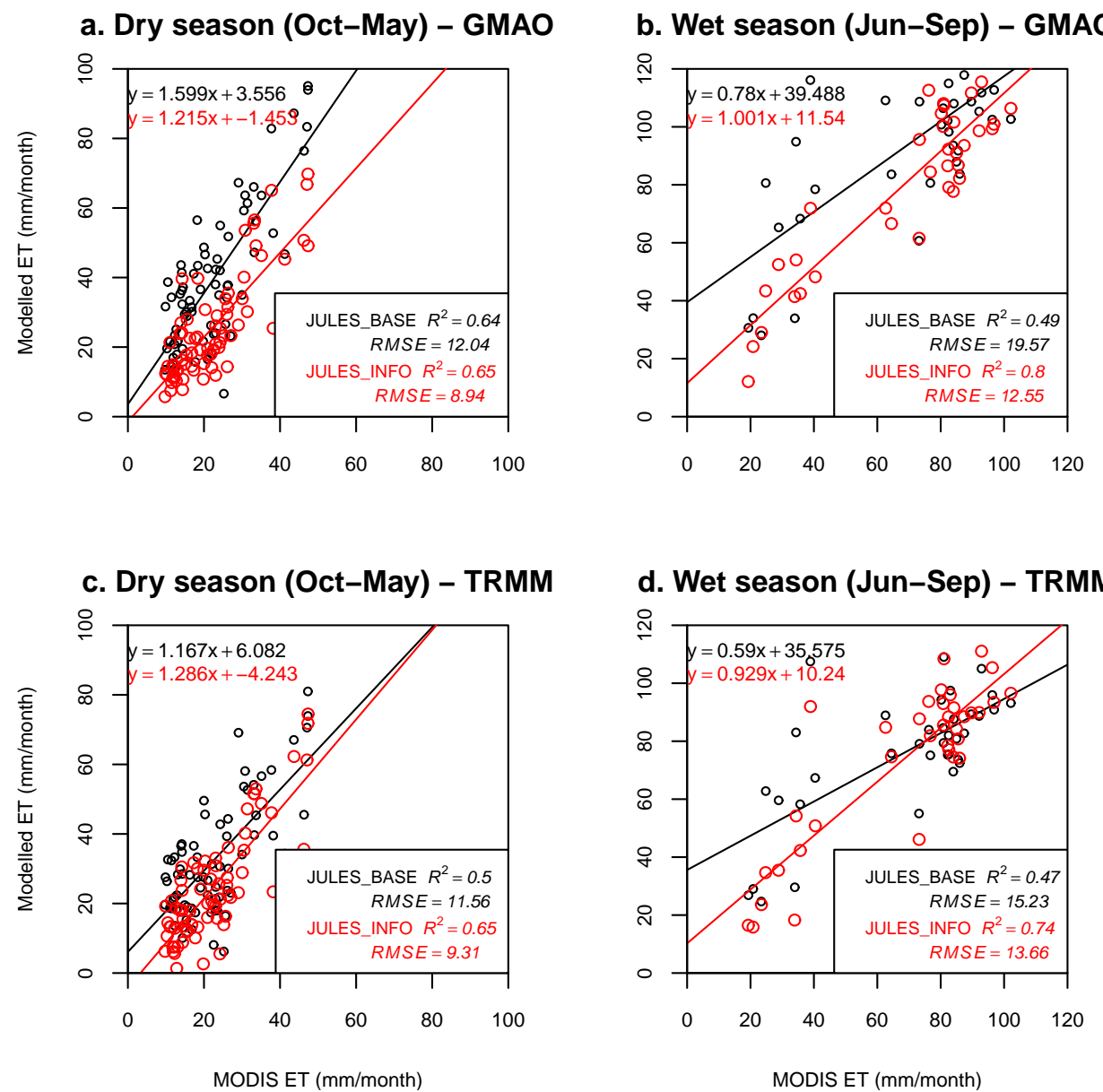

Figure 10. Results showing coefficient of determination $\left(R^{2}\right)$ and RMSE values are partitioned into wet (June-September) and dry (OctoberMay) periods.

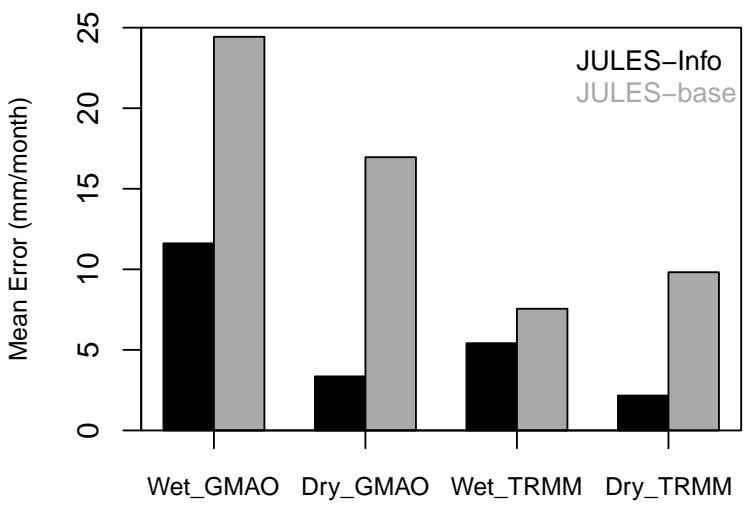

Figure 11. Mean error showing the discrepancy between both versions of JULES and MODIS ET.

(Fig. 6): $R^{2}$ increased from 0.77 to 0.90 under GMAO forcing data and from 0.71 to 0.87 under TRMM/NCEP data. RMSE decreased from 16.27 to 10.53 under GMAO forcing data and from 14.78 to 11.27 under TRMM/NCEP data.
Similar information arises from the spatial comparison of the modelled ET with the MODIS product, shown in Figs. 7 and 8 , for wet and dry periods respectively (TRMM forcing). Within the JULES-base and JULES-Info models the spatial ET variations are attributable to differences in soil parameters, precipitation and other meteorological variables aside from the vegetation parameters. However, it is evident that JULES-Info generates lower ET values which match better the MODIS values, compared to JULES-base.

Looking at the mean annual ET in the study area (Fig. 9), JULES-Info is matching quite well the equivalent MODIS annual ET, whereas JULES-base constantly appears to give higher values. The mean difference in annual ET between JULES-base and JULES-Info is $140 \mathrm{~mm} \mathrm{yr}^{-1}$ under TRMM precipitation and $160 \mathrm{~mm} \mathrm{yr}^{-1}$ under GMAO precipitation. The mean difference in annual ET between JULES-base and MODIS is $179 \mathrm{~mm} \mathrm{yr}^{-1}$ under TRMM precipitation, whereas the equivalent value between JULES-Info and MODIS is $39 \mathrm{~mm} \mathrm{yr}^{-1}$. The same figures under GMAO precipitation show the same magnitude of difference $\left(233 \mathrm{~mm} \mathrm{yr}^{-1}\right.$ difference between JULES-base and MODIS and $73 \mathrm{~mm} \mathrm{yr}^{-1}$ 

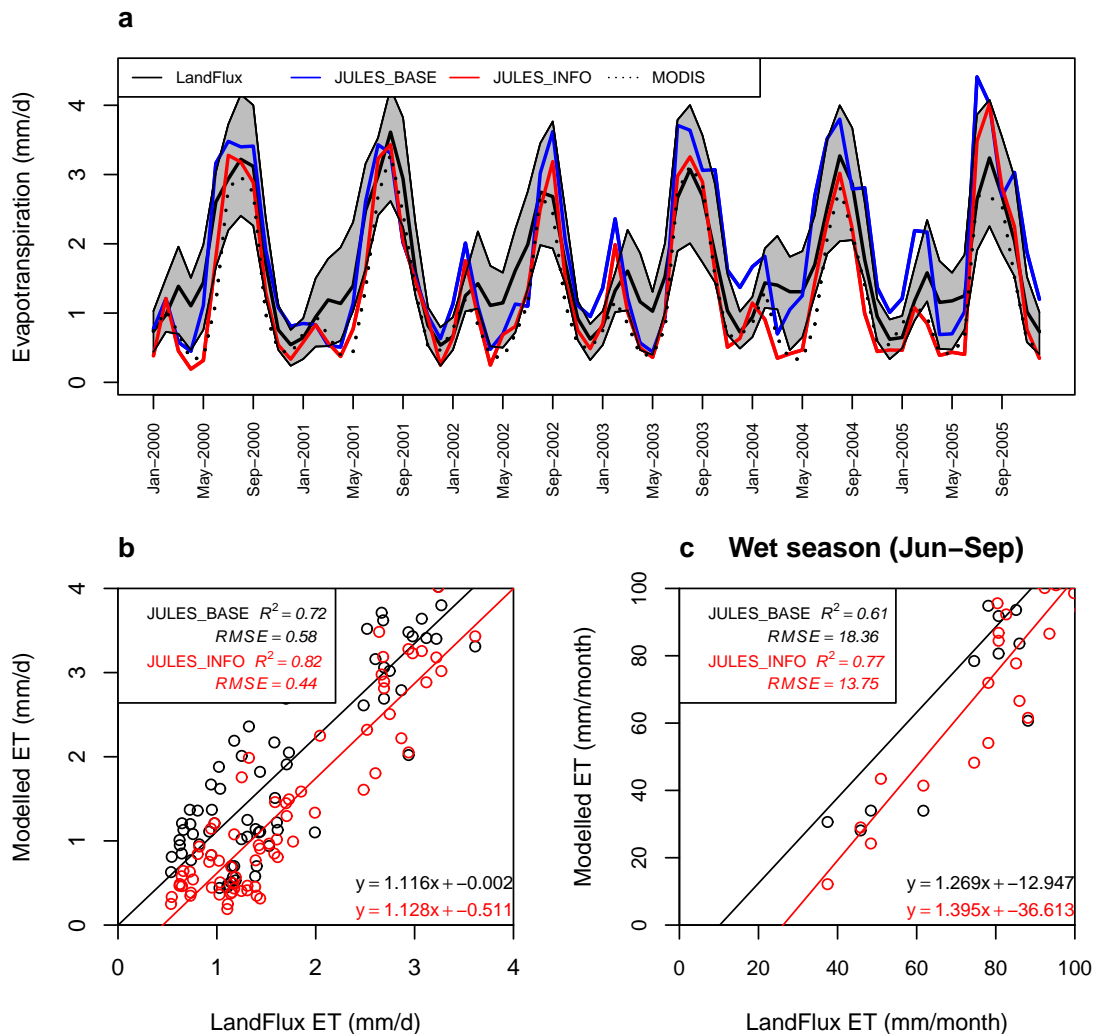

Figure 12. (a) Comparison of the modelled ET with the LandFlux-EVAL product. The shaded area corresponds to the values between the 25th and 75th percentiles of the distribution. (b) Performance scores of the two models (JULES-base and JULES-Info) in comparison with LandFlux-EVAL ET. (c) Results and performance scores only for wet (June-September) period.

a. Irrigated Wheat

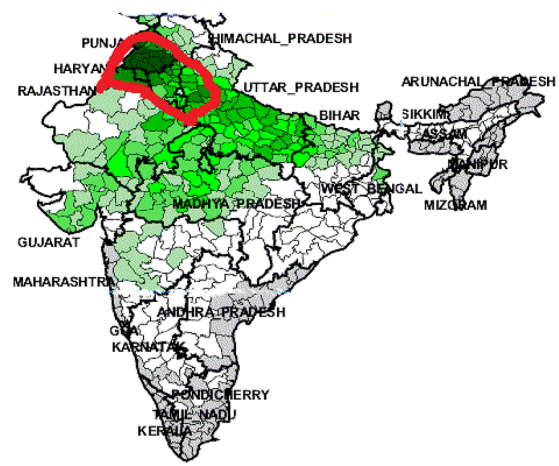

b. Rainfed Wheat

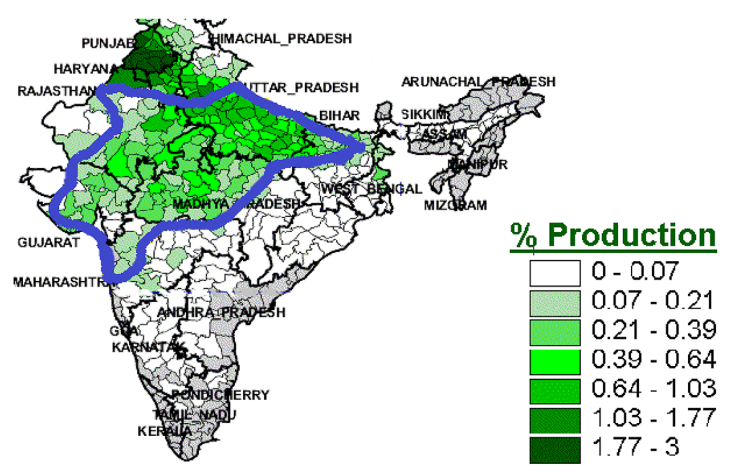

Figure 13. Map (a) shows the irrigated wheat growing areas of India. Map (b) shows the rain-fed wheat growing areas. Based on the location of our study area as shown in Fig. 1, most of the wheat grown in the UG Basin is rain-fed. Source: USDA-II (2013).

difference between JULES-Info and MODIS). Those results indicate a high sensitivity of the model with respect to vegetation dynamics.

In Figs. 10 and 11 we partition the results into wet (JuneSeptember) and dry (October-May) periods. $R^{2}$ and RMSE values are significantly improved during the wet period (Fig. 10), when the highest ET rates are being noticed in the study area. However, as shown in Fig. 11, which illus- trates the magnitude of the Mean Error for both the wet and dry seasons, the main improvement caused by JULES-Info occurs during the dry period, as the model is no longer constantly overestimating ET. In all cases JULES-Info achieves lower Mean Error values than JULES-base does.

Figure 12 shows the comparison of the modelled ET with the LandFlux-EVAL product. Similar behaviour is observed here as well. Coefficient of determination with JULES-Info 
is $R^{2}=0.82$ and is improved compared to the JULES-base equivalent value $\left(R^{2}=0.72\right)$. A noteworthy trend observed here is that during the spring season, both JULES-base and JULES-Info are underestimating ET when compared to the LandFlux-EVAL product. A possible explanation for this could be the fact that we do not account for irrigation. Different land cover maps, or forcing meteorology used by the LSMs that contributed in the calculation of LandFluxEVAL ET, could be related as well. However, looking at the wet period's ET, JULES-Info provides significantly improved results compared to JULES-base ( $R^{2}$ increased from 0.61 to 0.77 ).

As shown in Fig. 13 (source: USDA-II, 2013) most of the wheat that grows in our study area is rain fed. In addition, according to USDA-I (2013), rice in the district of Uttar Pradesh (which is the district our study area belongs to) is predominantly rain fed and depends largely on the monsoon season rains from June to September. Therefore, the simplification of not accounting for irrigation is not expected to affect significantly the results during the dry period. Furthermore, in JULES transpiration only occurs from the dry fraction of the canopy, which during and after a rain event is a very small part of the canopy. That means that transpiration during the wet season is not expected to change significantly even if irrigation was applied, since the dry portion of the canopy that transpires will remain the same. Nevertheless, it is possible that incorporation of irrigation in the coupled model will increase soil evaporation. The application of irrigation in the wet (dry) season could also have an impact in the dry (wet) season ET, as the soil moisture stores could be higher.

\section{Conclusions}

The objective of our study is to quantify the potential error in ET flux estimations of an LSM without dynamic vegetation. For this reason, the full energy balance scheme of JULES (which describes the exchange between atmospheresurface-subsurface water fluxes) has been coupled to the crop growth model InfoCrop, which represents the crop development and other physiological processes. The model has been parameterized for wheat and rice, the two main crops of the study area, in a two-crop rotating system. A crop calendar was added to the coupled system.

The results show that JULES is sensitive to the changes applied and the incorporation of crop dynamics in the model significantly alters the ET fluxes. An overall reduction is observed in the simulated ET fluxes of the JULES-Info model compared to the original JULES-base model. The seasonal patterns of ET as simulated by JULES-Info match better the MODIS and LandFlux-EVAL ET products than JULES-base does. The difference in mean annual ET between JULESbase and JULES-Info is approximately $150 \mathrm{~mm} \mathrm{yr}^{-1}$ and can be considered as an indication of the potential error in sur- face flux estimations of LSMs that do not include vegetation dynamics.

Improving the estimation of energy and water fluxes over croplands through a more accurate description of vegetation dynamics is crucial for projecting potential changes in the hydrological cycle under different climate change scenarios. Increased accuracy of ET estimations is an important step towards a better understanding of the temporal dynamics of climate-surface-groundwater fluxes as a function of agricultural production and inter-seasonal land cover change, while at the same time being vital for advanced irrigation practices under a water limited environment.

Acknowledgements. GMT is financially supported by the Grantham Institute for Climate Change. W. Buytaert and A. Mijic are supported by the NERC Changing Water Cycle (South Asia) project Hydrometeorological feedbacks and changes in water storage and fluxes in Northern India (grant number NE/I022558/1). The authors would like to thank P. K. Aggarwal and S. Naresh Kumar for sharing with them the InfoCrop model code.

Edited by: H. Cloke

\section{References}

Aggarwal, P., Kalra, N., Chander, S., and Pathak, H.: InfoCrop: a dynamic simulation model for the assessment of crop yields, losses due to pests, and environmental impact of agroecosystems in tropical environments. I. Model description, Agr. Syst., 89, 1-25, doi:10.1016/j.agsy.2005.08.001, 2006a.

Aggarwal, P., Banerjee, B., Daryaei, M. G., Bhatia, A., Bala, A., Rani, S., Chander, S., Pathak, H., and Kalra, N.: InfoCrop: A dynamic simulation model for the assessment of crop yields, losses due to pests, and environmental impact of agro-ecosystems in tropical environments. II. Performance of the model, Agr. Syst., 89, 47-67, doi:10.1016/j.agsy.2005.08.003, 2006b.

Agropedia: Agriculture Portal of IIT Kanpur, available at: http://agropedia.iitk.ac.in/content/ cropping-system-analysis-and-area-allocation-uttar-pradesh, last access: 19 September 2013.

Best, M. J., Pryor, M., Clark, D. B., Rooney, G. G., Essery, R .L. H., Ménard, C. B., Edwards, J. M., Hendry, M. A., Porson, A., Gedney, N., Mercado, L. M., Sitch, S., Blyth, E., Boucher, O., Cox, P. M., Grimmond, C. S. B., and Harding, R. J.: The Joint UK Land Environment Simulator (JULES), model description Part 1: Energy and water fluxes, Geosci. Model Dev., 4, 677-699, doi:10.5194/gmd-4-677-2011, 2011.

Bharati, L. and Jayakody, P.: Hydrology of the Upper Ganga river, International Water Management Institute, Colombo, Sri Lanka, 2010.

Blyth, E., Gash, J., Lloyd, A., Pryor, M., Weedon, G. P., and Shuttleworth, J.: Evaluating the JULES land surface model energy fluxes using FLUXNET Data, J. Hydrometeorol., 11, 509-519, 2010 . 
Blyth, E., Clark, D. B., Ellis, R., Huntingford, C., Los, S., Pryor, M., Best, M., and Sitch, S.: A comprehensive set of benchmark tests for a land surface model of simultaneous fluxes of water and carbon at both the global and seasonal scale, Geosci. Model Dev., 4, 255-269, doi:10.5194/gmd-4-255-2011, 2011.

Boegh, E., Thorsen, M., Butts, M., Hansen, S., Christiansen, J., Abrahamsen, P., Hasager, C., Jensen, N., van der Keur, P., Refsgaard, J., Schelde, K., Soegaard, H., and Thomsen, A.: Incorporating remote sensing data in physically based distributed agro-hydrological modelling, J. Hydrol., 287, 279-299, doi:10.1016/j.jhydrol.2003.10.018, 2004.

Calvet, J.-C., and Soussana, J.-F.: Modelling $\mathrm{CO}_{2}$-enrichment effects using an interactive vegetation SVAT scheme, Agr. Forest Meteorol., 108, 129-152, 2001.

Calvet, J.-C., Noilhanm, J., Roujean, J.-L., Bessemoulin, P., Cabelguenne, M., Olioso, A., and Wigneron, J.-P.: An interactive vegetation SVAT-model tested against data from six contrasting sites, Agr. Forest Meteorol., 92, 73-95, 1998.

Clark, D. B., Mercado, L. M., Sitch, S., Jones, C. D., Gedney, N., Best, M. J., Pryor, M., Rooney, G. G., Essery, R. L. H., Blyth, E., Boucher, O., Harding, R. J., Huntingford, C., and Cox, P. M.: The Joint UK Land Environment Simulator (JULES), model description - Part 2: Carbon fluxes and vegetation dynamics, Geosci. Model Dev., 4, 701-722, doi:10.5194/gmd-4-701-2011, 2011.

Collatz, G. J., Ball, J. T., Grivet, C., and Berry, J. A.: Physiological and environmental regulation of stomatal conductance, photosynthesis and transpiration: a model that includes a laminar boundary layer, Agr. Forest Meteorol., 54, 107-136, 1991.

Cosby, B. J., Hornberger, G. M., Clapp, R. B., and Ginn, T. R.: A statistical exploration of the relationships of soil moisture characteristics to the physical properties of soils, Water Resour. Res., 20, 682-690, doi:10.1029/WR020i006p00682, 1984.

Cox, P. M.: Description of the "TRIFFID” Dynamic Global Vegetation Model, Hadley Center Technical Note 24, Hadley Centre, Met Office., London Road, Bracknell, Berks, RG122SY, UK, 2001.

Cox, P. M., Huntingford, C., and Harding, R. J.: A canopy conductance and photosynthesis model for use in a GCM land surface scheme, J. Hydrol., 212, 79-94, 1998.

Cox, P. M., Betts, R. A., Jones, C. D., Spall, S. A., and Totterdell, I. J.: Acceleration of global warming due to carbon-cycle feedbacks in a coupled climate model, Nature, 408, 184-187, 2000.

Dai, Y., Zeng, X., Dickinson, R. E., Baker, I., Bonan, G., Bosilovich, M., Denning, S., Dirmeyer, P., Houser, P., Niu, G., Oleson, K., Schlosser, A., and Yang, Z.-L.: The common land model (CLM), B. Am. Meteorol. Soc., 84, 1013-1023, doi:10.1175/BAMS-848-1013, 2003.

Essery, R., Best, M., Betts, R., and Taylor, C.: Explicit representation of subgrid heterogeneity in a GCM land surface scheme, J. Hydrometeorol., 4, 530-543, 2003.

FAO: AQUASTAT. Information System on Water and Agriculture, available at: http://www.fao.org/nr/water/aquastat/water_ use_agr/CC_PDF/CC_IND.pdf, last access: 19 September 2013.

FAO: FAO/IIASA/ISRIC/ISSCAS/JRC. Harmonized World Soil Database (version 1.1), FAO, Rome, Italy and IIASA, Laxenburg, Austria., available at: http://webarchive.iiasa.ac.at/ Research/LUC/External-World-soil-database/HTML/ (last access: 24 January 2013), 2009.
Friedl, M. A., McIver, D. K., Hodges, J. C. F., Zhang, X. Y., Muchoney, D., and Strahler, A. H. E. A.: Global land cover mapping from MODIS: algorithms and early results, Remote Sens. Environ., 83, 287-302, 2002.

Guo, Z., Dirmeyer, P. A., Koster, R. D., Sud, Y. C., Bonan, G., Oleson, K. W., Chan, E., Verseghy, D., Cox, P., Gordon, C. T., McGregor, J. L., Kanae, S., Kowalczyk, E., Lawrence, D., Liu, P., Mocko, D., Lu, C.-H., Mitchell, K., Malyshev, S., McAvaney, B., Oki, T., Yamada, T., Pitman, A., Taylor, C. M., Vasic, R., and Xue, Y.: GLACE: The Global Land-Atmosphere Coupling Experiment. Part II: Analysis, J. Hydrometeorol., 7, 611-625, 2006.

Huffman, G. J. and Bolvin, D. T.: Trmm and other data precipitation data set documentation, available at: ftp://precip.gsfc.nasa. gov/pub/trmmdocs/3B42_3B43_doc.pdf, last access: 16 December 2013 .

Huffman, G. J., Bolvin, D. T., Nelkin, E. J., Wolff, D. B., Adler, R. F., Gu, G., Hong, Y., Bowman, K. P., and Stocker, E. F.: The TRMM Multisatellite Precipitation Analysis (TMPA): quasi-global, multiyear, combined-sensor precipitation estimates at fine scales, J. Hydrometeorol., 8, 38-55, 2007.

ICAR: Crop Calendar of Major Crops, available at: http://www.icar. org.in/en/crop-science.htm, last access: 18 September 2013.

Jin, Y., Schaaf, C. B., Woodcock, C. E., Gao, F., Li, X., Strahler, A. H., Lucht, W., and Liang, S.: Consistency of MODIS surface bidirectional reflectance distribution function and albedo retrievals: 2. Validation, J. Geophys. Res., 108, 4159, doi:10.1029/2002JD002804, 2003.

Kalnay, E., Kanamitsu, M., Kistler, R., Collins, W., Deaven, D., Gandin, L., Iredell, M., Saha, S., White, G., Woollen, J., Zhu, Y., Leetmaa, A., Reynolds, R., Chelliah, M., Ebisuzaki, W., Higgins, W., Janowiak, J., Mo, K., Ropelewski, C., Wang, J., Jenne, R., and Joseph, D.: The NCEP/NCAR 40-Year Reanalysis Project, B. Am. Meteorol. Soc., 77, 437-471, 1996.

Koster, R., Dirmeyer, P., Guo, Z., and Bonan, G.: Regions of strong coupling between soil moisture and precipitation, Science, 305 , 1138-1140, 2004.

Koster, R. D., Sud, Y. C., Guo, Z., Dirmeyer, P. A., Bonan, G., Oleson, K. W., Chan, E., Verseghy, D., Cox, P., Davies, H., Kowalczyk, E., Gordon, C. T., Kanae, S., Lawrence, D., Liu, P., Mocko, D., Lu, C.-H., Mitchell, K., Malyshev, S., McAvaney, B., Oki, T., Yamada, T., Pitman, A., Taylor, C. M., Vasic, R., and Xue, Y.: GLACE: the Global Land-Atmosphere Coupling Experiment. Part I: Overview, J. Hydrometeorol., 7, 590-610, 2006.

Krishna Kumar, K., Rupa Kumar, K., Ashrit, R. G., Deshpande, N. R., and Hansen, J. W.: Climate impacts on Indian agriculture, Int. J. Climatol., 24, 1375-1393, 2004.

Lavender, S. L., Taylor, C. M., and Matthews, A. J.: Coupled landatmosphere intraseasonal variability of the West African Monsoon in a GCM, J. Climate, 23, 5557-5571, 2010.

Lei, H., Yang, D., Lokupitiya, E., and Shen, Y.: Coupling land surface and crop growth models for predicting evapotranspiration and carbon exchange in wheat-maize rotation croplands, Biogeosciences, 7, 3363-3375, doi:10.5194/bg-7-3363-2010, 2010.

Li, Y., Kinzelbach, W., Zhou, J., Cheng, G. D., and Li, X.: Modelling irrigated maize with a combination of coupled-model simulation and uncertainty analysis, in the northwest of China, Hydrol. Earth Syst. Sci., 16, 1465-1480, doi:10.5194/hess-16-14652012, 2012. 
Li, Y., Zhou, J., Kinzelbach, W., Cheng, G., Li, X., and Zhao, W.: Coupling a SVAT heat and water flow model, a stomatalphotosynthesis model and a crop growth model to simulate energy, water and carbon fluxes in an irrigated maize ecosystem, Agr. Forest Meteorol., 176, 10-24, 2013.

Lucht, W., Schaaf, C., and Strahler, A.: An algorithm for the retrieval of albedo from space using semiempirical BRDF models, IEEE T. Geosci. Remote, 38, 977-998, 2000.

Maruyama, A. and Kuwagata, T.: Coupling land surface and crop growth models to estimate the effects of changes in the growing season on energy balance and water use of rice paddies, Agr. Forest Meteorol., 150, 919-930, 2010.

Meehl, G. A.: Influence of the land surface in the Asian Summer Monsoon: external conditions versus internal feedbacks, J. Climate, 7, 1033-1049, 1994.

GMAO: Global Modeling and Assimilation Office. File Specification for GEOS-DAS Gridded Output Version 5.3. Document No. GMAO-1001v5.3, Tech. rep., Maryland, USA, 2004.

Mo, X., Liu, S., Lin, Z., Xu, Y., Xiang, Y., and McVicar, T.: Prediction of crop yield, water consumption and water use efficiency with a SVAT-crop growth model using remotely sensed data on the North China plain, Ecol. Model., 183, 301-322, 2005.

Mu, Q., Heinsch, F. A., Zhao, M., and Running, S. W.: Development of a global evapotranspiration algorithm based on MODIS and global meteorology data, Remote Sens. Environ., 111, 519-536, doi:10.1016/j.rse.2007.04.015, 2007.

Mu, Q., Zhao, M., and Running, S. W.: Improvements to a MODIS global terrestrial evapotranspiration algorithm, Remote Sens. Environ., 115, 1781-1800, doi:10.1016/j.rse.2011.02.019, 2011.

Mueller, B., Hirschi, M., Jimenez, C., Ciais, P., Dirmeyer, P. A., Dolman, A. J., Fisher, J. B., Jung, M., Ludwig, F., Maignan, F., Miralles, D. G., McCabe, M. F., Reichstein, M., Sheffield, J., Wang, K., Wood, E. F., Zhang, Y., and Seneviratne, S. I.: Benchmark products for land evapotranspiration: LandFlux-EVAL multi-data set synthesis, Hydrol. Earth Syst. Sci., 17, 3707-3720, doi:10.5194/hess-17-3707-2013, 2013.

Myneni, R. B., Hoffman, S., Knyazikhin, Y., Privette, J. L., Glassy, J., Tian, Y., Wang, Y., Song, X., Zhang, Y., Smith, G. R., Lotsch, A., Friedl, M., Morisette, J. T., Votava, P., Nemani, R. R., and Running, S. W.: Global Products Of Vegetation Leaf Area And Fraction Absorbed PAR From Year One Of MODIS Data, Remote Sens. Environ., 83, 214-231, 2002.

NFSM: Crop Calendar Report, available at: http://nfsm.gov.in/ nfsmmis/RPT/CalenderReport.aspx, last access: 19 September 2013.

Osborne, T. M., Lawrence, D. M., Challinor, A. J., Slingo, J. M., and Wheeler, T. R.: Development and assessment of a coupled crop-climate model, Glob. Change Biol., 13, 169-183, doi:10.1111/j.1365-2486.2006.01274.x, 2007.

Osborne, T., Slingo, J., Lawrence, D., and Wheeler, T.: Examining the interaction of growing crops with local climate using a coupled crop-climate model, J. Climate, 22, 1393-1411, 2009.

Pauwels, V. R. N., Verhoest, N. E. C., De Lannoy, G. J. M., Guissard, V., Lucau, C., and Defourny, P.: Optimization of a coupled hydrology - crop growth model through the assimilation of observed soil moisture and leaf area index values using an ensemble Kalman filter, Water Resour. Res., 43, W04421, doi:10.1029/2006WR004942, 2007.
Penman, H. L.: Natural evaporation from open water, bare soil and grass, P. Roy. Soc. Lond. A Mat., 193, 120-145, 1948.

Penning de Vries, F., Jansen, D., ten Berge, H., and Bakema, A.: Simulation of Ecophysiological Processes of Growth in Several Annual Crops, Simulation Monograph PUDOC, Wageningen, the Netherlands, 1989.

Richards, L. A.: Capillary conduction of liquids through porous mediums, J. Appl. Phys., 1, 318-333, doi:10.1063/1.1745010, 1931.

Sellers, P.: Canopy reflectance, photosynthesis and transpiration, Int. J. Remote Sens., 6, 1335-1372, 1985.

Seneviratne, S. I., Koster, R. D., Guo, Z., Dirmeyer, P. A., Kowalczyk, E., Lawrence, D., Liu, P., Mocko, D., Lu, C.-H., Oleson, K. W., and Verseghy, D.: Soil moisture memory in AGCM simulations: analysis of Global Land Atmosphere Coupling Experiment (GLACE), J. Hydrometeorol., 7, 1090-1112, 2006.

Sheehy, J. E., Mitchell, P. L., and Hardy, B.: Redesigning Rice Photosynthesis to Increase Yield, 1st Edn, Elsevier, Amsterdam, the Netherlands, 2000.

Sheffield, J., Goteti, G., and Wood, E.: Development of a 50year high-resolution global dataset of meteorological forcings for land surface modeling, J. Climate, 19, 3088-3111, doi:10.1175/JCLI3790.1, 2006.

Taylor, C. M. and Ellis, R. J.: Satellite detection of soil moisture impacts on convection at the mesoscale, Geophys. Res. Lett., 33, L03404, doi:10.1029/2005GL025252, 2006.

Tsarouchi, G., Mijic, A., Moulds, S., and Buytaert, W.: Historical and future land-cover changes in the Upper Ganges basin of India, Int. J. Remote Sens., 35, 3150-3176, 2014.

Tsvetsinskaya, E. A., Mearns, L. O., and Easterling, W. E.: Investigating the effect of seasonal plant growth and development in three-dimensional atmospheric simulations. Part I: Simulation of surface fluxes over the growing season, J. Climate, 14, 692-709, 2001.

Turner, A. G. and Annamalai, H.: Climate change and the South Asian summer monsoon, Nature Clim. Change, 2, 587-595, 2012.

USDA-I: Crop Information - Crop Descriptions, available at: www.fas.usda.gov/remote/, last access: 10 November 2013.

USDA-II: Irrigated and rainfed wheat - India, 2013.

USDA-II: PECAD-FAS (Production Estimates and Crop Assessment Division of USDA's Foreign Agricultural Service), 2013.

Van den Hoof, C., Hanert, E., and Vidale, P. L.: Simulatind dynamic crop growth with an adapted land surface model JULESSUCROS: model development and validation, Agr. Forest Meteorol., 151, 137-153, doi:10.1016/j.agrformet.2010.09.011, 2011.

Van den Hoof, C., Vidale, P. L., Verhoef, A., and Vincke, C.: Improved evaporative flux partitioning and carbon flux in the land surface model JULES: impact on the simulation of land surface processes in temperate Europe, Agr. Forest Meteorol., 181, 108124, doi:10.1016/j.agrformet.2013.07.011, 2013.

van Genuchten, M. T.: a closed-form equation for predicting the hydraulic conductivity of unsaturated soils, Soil Sci. Soc. Am. J., 44, 892-898, 1980.

Van Laar, H., Goudrian, J., and van Keulen, H.: Crop Growth Simulation Model "SUCROS97": Simulation of Crop Growth for Potential and Water-Limited Production Situations as Applied to Spring Wheat. Tech. Rep. AB-DLO, Wageningen, The Netherlands, 1988. 
Zulkafli, Z., Buytaert, W., Onof, C., Lavado, W., and Guyot, J. L.: A critical assessment of the JULES land surface model hydrology for humid tropical environments, Hydrol. Earth Syst. Sci., 17, 1113-1132, doi:10.5194/hess-17-1113-2013, 2013a.
Zulkafli, Z., Buytaert, W., Onof, C., Manz, B., Tarnavsky, E., Lavado, W., and Guyot, J.-L.: A comparative performance analysis of TRMM 3B42 (TMPA) versions 6 and 7 for hydrological applications over Andean-Amazon river basins, J. Hydrometeorol., 15, 581-592, $2013 b$. 